\title{
Okul Öncesi Öğretmen ve Öğretmen Adaylarının Kaynaştırmaya Yönelik Görüşlerinin Karşılaştırılması*
}

\section{Comparison of Pre-School Teachers' and Preservice Teachers' Views on Inclusion}

\author{
Berrin AKMAN**, Elif MERCAN UZUN***, Dila Nur YAZICI****
}

\begin{abstract}
Öz: Bu çalışmanın amacı okul öncesi öğretmenlerinin ve okul öncesi öğretmen adaylarının kaynaştırmaya yönelik görüşlerinin incelenmesidir. Nitel araştırma yöntemlerinden durum çalışması kullanılarak desenlenen araştırmada çalı̧̧ma grubunu maksimum çeşitlilik örneklemesine göre seçilen 30 okul öncesi öğretmeni ve 30 okul öncesi öğretmen adayı oluşturmaktadır. Araştırmanın verileri içerik analiziyle analiz edilmiş olup, analizler sonucunda okul öncesi öğretmen ve öğretmen adaylarının kaynaştırmayı genellikle özel gereksinimli çocukların genel eğitim sınıflarında eğitim alması olarak tanımladıkları, kaynaştırmanın birçok açıdan yararı olduğu gibi dezavantajı olduğunu düşündükleri noktalar olduğunu düşündükleri, kaynaştırmanın başarılı olabilmesi için uygun etkinlikler hazırlayabilecekleri, sınıfta fiziki düzenlemeler yapabilecekleri, diğer çocukları ve aileleri bilgilendirebilecekleri belirlenmiştir. Bulgular ilgili alanyazın ışığında tartışılmış olup, sonuçlara paralel olarak öneriler getirilmiştir.

Anahtar Kelimeler: Okul öncesi eğitimde kaynaştırma, okul öncesi öğretmenleri, okul öncesi öğretmen adayları, kaynaştırma
\end{abstract}

\begin{abstract}
The purpose of this study is to examine the views of the pre-school teachers and preservice teachers about the inclusion. The study group which was designed by using case study of qualitative research methods is constituted of 30 preschool teachers and 30 preservice preschool teachers who were selected according to the maximum diversity sample. The analyses of the research were done by content analysis and the results of the analyses showed that pre-school teachers and preservice teachers are more likely to be involved in the process of integrating, generally speaking, that special needs children are defined as receiving education in general education classes, and that inclusion is, in many respects, beneficial. They can make physical arrangements in the class, inform other children and their families. Findings have been discussed in the light of related literature and suggestions have been made in parallel with the results.

Keywords: Inclusion in preschool education, preschool teachers, preschool teacher candidates, inclusion
\end{abstract}

\section{Giriș}

Özel gereksinimli çocukların eğitiminde farklı yaklaşımlar benimsenmiş olup, bu yaklaşımlardan biri olan kaynaştırma eğitimi yirminci yüzyılın özellikle ikinci yarısından itibaren yaygınlaşma göstermiştir. Kaynaştırma, Lewis ve Doorlog (1987) tarafindan, normal eğitim kurumlarına yerleştirilmesini engelleyecek ve bu kurumlara uyumlarını zorlaştıracak kadar ağır derecede engeli olmayan ya da davranışsal problemleri olmayan çocukların, normal eğitim programlarına yerleştirilmesi olarak tanımlanmaktadır. Johnson ve Johnson (1980) kaynaştırmayı; engelli çocukların normal gelişim gösteren akranlarıyla daha olumlu ilişkiler kurmasını kolaylaştırıcı ortamın sağlanması şeklinde tanımlamaktadır. Özel Eğitim Hizmetleri Yönetmeliği’de (2016) kaynaştırma; özel eğitime ihtiyacı olan bireylerin eğitimlerini, destek eğitim hizmetleri de sağlanarak yetersizliği olmayan akranları ile birlikte resmî ve özel; okul öncesi, ilköğretim, orta öğretim ve yaygın eğitim kurumlarında sürdürmeleri esasına dayanan özel eğitim uygulamaları olarak tanımlanmıştır.

\footnotetext{
*Bu çalışma 11-13 Kasım 2016 tarihleri arasında gerçekleştirilen II. Uluslararası Çocuk Koruma Kongresi’nde sözlü bildiri olarak sunulmuştur.

**Prof. Dr., Hacettepe Üniversitesi Eğitim Fakültesi, Ankara-Türkiye, e-posta: bakman@ @acettepe.edu.tr ***Dr. Öğretim Üyesi, On Dokuz Mayıs Üniversitesi, Eğitim Fakültesi, Samsun-Türkiye, e-posta: emercan@omu.ed.utr ****Arş. Gör., Hacettepe Üniversitesi Eğitim Fakültesi, Ankara-Türkiye, e-posta: dilayazici@ hacettepe.edu.tr
} 
Kaynaştırmaya yönelik farklı görüşlerin ve çabaların oluşmaya başladığı 20. Yüzyılın ilk yarısında sınırlı da olsa bazı çalışmalar dikkat çekmektedir. Görme engelli çocuklar için 1913 yılında başlatılan kaynaştırma programı ilk uygulamalar arasında yer almaktadır. İngiltere' de 1928 yılında alınan bir kararla özel eğitim ve genel eğitim okulları birlikte çalışmaya başlamıştır. Bu kararın ardından 1944 yılında kabul edilen yasa ile uygun olan çocukların genel eğitim sınıflarında eğitimlerini sürdürmeleri görüşü benimsenmiştir. Amerika'da 1930'lu yıllardan sonra özel gereksinimli çocuklara yönelik 1lımlı tutumlar gelişmeye başlamış ve Beyaz Saray' da düzenlenen Sakat Çocuklar Konferansı engelli çocukları da içeren eğitim planlamasının ulusal düzeyde devlet politikası olarak alınmasına neden olmuştur. Amerika Birleşik Devletleri'nde 1950'li yıllarda özel gereksinimli çocuklara bakım veren yatılı okullar kapatılarak, yeni yatılı okulların açılması tamamen durdurulmuştur. Bununla birlikte tıp, eğitim, psikoloji, konuşma, işitme gibi disiplinlerde 1950 yılından sonra bütünleşme görülmüştür (Aral, 2010).

Kaynaştırma açısından 1960'lardan sonraki dönemde en çarpıcı ve en hızlı gelişmelerin ortaya çıktığı görülmektedir. Kaynaştırma, 1960’lı yıllarda, tüm çocuklara eşit eğitim firsatları verilmesi gerektiği görüşünden yola çıkan bir felsefe olarak ortaya çıkmış ve bu görüş sonucunda, özel gereksinimli çocuklar normal sınıflara yerleştirilmeye başlanmıştır. Bu dönemde kaynaştırmanın daha fazla kabul görmesinde özel eğitim sınıflarında verilen eğitimin beklenen yararı sağlamaması, çocukların sosyal yönden uyumlarını güçleştirmesi, özel eğitim sınıflarında verilen eğitime karş1 eleştirilerin artması, davaların açılması ve baskı gruplarının oluşması, kaynaştırma ile ilgili yasal düzenlemelerin yapılması gibi etmenler etkili olmuştur (Aral, 2010).

Öğretmen ve öğretmen adaylarının kaynaştırmaya karşı tutumları, kaynaştırmanın başarıya ulaşmasındaki en önemli faktörlerden biri olarak karşımıza çıkmaktadır. Dolayısıyla öğretmenlerin lisans eğitimlerinden itibaren kaynaştırmanın hem özel gereksinimli çocuk, hem normal gelişim gösteren çocuk, hem aileler hem de kendileri açısından önemli olduğunun farkında olmaları önemli bir durum olarak karşımıza çıkmaktadır. Kaynaştırmayla ilgili yapılan alan yazın incelendiğinde; okul öncesi öğretmen ve öğretmen adaylarının kaynaştırmaya yönelik düşüncelerinin genellikle nicel yöntemlerle araştırıldığı (Artan ve Uyanık Balat, 2003; Bruns ve Mogharreban, 2007; Buell, Hallam, Gamel-McCormick ve Scheer, 1999; Özdemir, 2010; Sarı, Çeliköz ve Seçer, 2009; Seçer, 2010; Sucuoğlu, Bakkaloğlu, Karasu, Demir ve Akalın, 2013; Stolber, Gettinger ve Goetz, 1998; Şahbaz ve Kalay, 2010; Temel, 2000), katılımcıların derinlemesine görüşlerinin alındığı nitel araştırmalara dayalı çalışmaların ise (Gök ve Erbaş, 2011; Leatherman, 2007) sınırlı sayıda kaldığı görülmesi nedeniyle bu araştırmada okul öncesi öğretmen ve öğretmen adaylarının kaynaştırmaya yönelik görüşleri nitel desen kullanılarak incelenmiştir. Bu amaçla ilgili alanyazın ışığında (Aral, 2010; Gök ve Erbaş 2011; Macy ve Carter, 1978; Nutbrown ve Clough, 2007; Sucuoğlu ve diğerleri, 2013) sorular hazırlanmış, uzman görüşleri doğrultusunda araştırma sorularına son hali verilmiştir. Aşağıda katılımcılara yöneltilen sorular yer almaktadır.

1. Okul öncesi öğretmenleri ve öğretmen adayları kaynaştırma kavramını nasıl tanımlamaktadır?

2. Okul öncesi öğretmenleri ve öğretmen adayları kaynaştırma eğitiminin avantajlarının neler olduğunu düşünmektedir?

3. Okul öncesi öğretmenleri ve öğretmen adayları kaynaştırma eğitiminin dezavantajlarının neler olduğunu düşünmektedir?

4. Okul öncesi öğretmenleri ve öğretmen adayları hangi özel gereksinim gruplarının kaynaştırmaya alınacağını düşünmektedir?

5. Okul öncesi öğretmenleri ve öğretmen adayları hangi özel gereksinim gruplarının kaynaştırmaya alınmayacağını düşünmektedir?

6. Okul öncesi öğretmenleri ve öğretmen adayları kaynaştırma eğitiminin başarıya ulaşmasında neler yapılabileceğini düşünmektedir?

7. Okul öncesi öğretmenleri ve öğretmen adayları kaynaştırma eğitiminin haftada ne kadar süreyle verilmesi gerektiğini düşünmektedir?

8. Okul öncesi öğretmenleri ve öğretmen adayları kaynaştırma eğitiminin neden önemli olduğunu düşünmektedir? 


\section{Yöntem}

\section{Araştırma modeli}

Okul öncesi öğretmen ve öğretmen adaylarının kaynaştırmaya yönelik görüşlerini derinlemesine incelemeyi ve karşılaştırmayı amaçlayan bu çalışma, nitel desende oluşturulmuştur. Sosyoloji, antropoloji, psikoloji, felsefe dilbilim gibi çeşitli disiplinlere dayanan kuramsal temelleri olan nitel araştırma, "gözlem, görüşme ve doküman analizi gibi nitel veri toplama yöntemlerinin kullanıldığı, algıların ve olayların doğal ortamda gerçekçi ve bütüncül bir biçimde ortaya konmasına yönelik nitel bir sürecin izlendiği araştırma" olarak tanımlanmaktadır (Yıldırım, 1999). Nitel araştırmalar derinlemesine betimleme, yorumlama ve katılımcıların bakış açılarını anlamayı amaçlamaktadır (Glesne ve Peskin, 1992). Kültür analizi, olgubilim, durum çalışması, eylem araştırması ve kuram oluşturma olmak üzere nitel araştırmanın beş farklı deseni vardır. $\mathrm{Bu}$ çalışma nitel araştırma desenlerinden durum çalışması kullanılarak desenlenmiştir. Durum çalışması, "araştırmacının gerçek yaşam, güncel sınırlı bir sistem ya da belli bir zaman içerisindeki çoklu sınırlandırılmış sistemler hakkında çoklu bilgi kaynakları aracılığıyla detaylı ve derinlemesine bilgi topladığı, bir durum betimlemesi ya da durum temaları ortaya koyduğu nitel bir yaklaşımdır (Creswell, 2013). Bu çalışmada durum çalışması türlerinden çoklu durum çalışması kullanılmıştır.

\section{Çalışma grubu}

Okul öncesi öğretmen ve öğretmen adaylarının kaynaştırmaya yönelik görüşlerini karşılaştırmayı amaçlayan bu çalışmanın katılımcılarını Samsun'da görev yapmakta olan 30 okul öncesi öğretmeni ve Ondokuz Mayıs Üniversitesi'nde dördüncü sınıfta öğrenim görmekte olan 30 okul öncesi öğretmen adayı oluşturmaktadır. Katılımcı öğretmen ve öğretmen adaylarının belirlenmesinde amaçlı örnekleme yöntemlerinden biri olan maksimum çeşitlilik örneklemesi kullanılmıştır. Maksimum çeşitlilik örneklemesinde katılımcılar geniş bir yelpazeden amaçlı olarak seçilmektedir (Johnson ve Christensen, 2014).

Araştırma konusu hakkında farklı deneyimlere ya da düşüncelere sahip olan okul öncesi öğretmenlerinin ve öğretmen adaylarının çeşitliliğini sağlamak amacıyla bu örnekleme yöntemi çalışma için uygun bulunmuştur (Yıldırım ve Şimşek, 2011). Bu nedenle araştırmaya katılan öğretmenler değişik türdeki ve yerdeki okullardan seçilmiş, öğretmenlerin kıdemlerinde çeşitlik olmasına dikkat edilmiştir. Katılımcılara ait bilgilere Tablo 1'de yer verilmiştir.

Tablo 1 incelendiğinde araştırmaya katılan okul öncesi öğretmenlerinin 25'inin kadın, beşinin erkek, dokuzunun 21-24, dokuzunun 25-29, 6'sının 30-34, 7'sinin 35-39 ve 5'inin 40-44 yaş aralığında olduğu, 14'ünün 0-4, birinin 5-9, sekizinin 10-14, beşinin 15-19 y1l ve ikisinin 20 yıl ve üzeri kıdeme sahip olduğu, 22 öğretmenin kaynaştırmaya yönelik ders/seminer aldığı, sekiz öğretmenin ise bu konuda herhangi bir eğitim almadığı, 27 öğretmenin daha önce kaynaştırma öğrencisi olduğu, üç öğretmenin olmadığı, öğretmenlerin 13'ünün sınıfında araştırmanın yapıldığı dönemde kaynaştırma öğrencisinin olduğu, 17'sinin sınıfında ise bu dönemde bir kaynaştırma öğrencisi olmadığı; öğretmen adaylarının 24'ünün kadın, altısının erkek, tüm öğretmen adaylarının kaynaştırmaya yönelik eğitim/seminer aldığı, 14 öğretmenin uygulama dersleri kapsamında kaynaştırma öğrencisi olduğu, 16'sının olmadığı görülmektedir.

Tablo 1

Demografik Bilgiler.

\begin{tabular}{lll}
\hline Öğretmen & & \\
\hline \multirow{2}{*}{ Cinsiyet } & Kadın & 25 \\
& Erkek & 5 \\
\hline \multirow{3}{*}{ Yaş } & $21-24$ & 9 \\
& $25-29$ & 9 \\
& $30-34$ & 6 \\
& $35-39$ & 7 \\
& $40-44$ & 5 \\
\multirow{2}{*}{ Kidem } & 45 ve üzeri & 4 \\
& $0-4$ y11 & 14 \\
& $5-9$ y11 & 1 \\
& $10-14$ y1l & 8
\end{tabular}




\begin{tabular}{|c|c|c|}
\hline & $\begin{array}{l}15-19 \text { y1l } \\
20 \text { y1l ve üzeri }\end{array}$ & $\begin{array}{l}5 \\
2 \\
\end{array}$ \\
\hline \multirow{2}{*}{$\begin{array}{l}\text { Kaynaştırmaya yönelik } \\
\text { ders /seminer alma durumu }\end{array}$} & Evet & 22 \\
\hline & Hayır & 8 \\
\hline \multirow{2}{*}{$\begin{array}{l}\text { Sınıfında daha önce } \\
\text { kaynaştırma eğitimi alan } \\
\text { çocuk olma durumu }\end{array}$} & Evet & 27 \\
\hline & Hayır & 3 \\
\hline \multirow{2}{*}{$\begin{array}{l}\text { Sınıfında şu anda } \\
\text { kaynaştırma eğitimi alan } \\
\text { çocuk olma durumu }\end{array}$} & Evet & 13 \\
\hline & Hayır & 17 \\
\hline \multirow{6}{*}{$\begin{array}{l}\text { Çocukların özel gereksinim } \\
\text { durumu }\end{array}$} & Hafif düzeyde zihinsel gerilik & 4 \\
\hline & Otizm & 4 \\
\hline & İşitme engelli & 2 \\
\hline & Fiziksel engelli & 1 \\
\hline & DEHB & 1 \\
\hline & Görme Engelli & 1 \\
\hline \multicolumn{3}{|l|}{ Öğretmen aday1 } \\
\hline \multirow{2}{*}{ Cinsiyet } & Kadın & 24 \\
\hline & Erkek & 6 \\
\hline \multirow{2}{*}{$\begin{array}{l}\text { Kaynaştırmaya yönelik } \\
\text { ders /seminer alma durumu }\end{array}$} & Evet & 30 \\
\hline & Hayır & 0 \\
\hline \multirow{2}{*}{$\begin{array}{l}\text { Okul Deneyimi ve } \\
\text { Öğretmenlik } \\
\text { Uygulaması'nda } \\
\text { kaynaştırma eğitimi alan } \\
\text { çocuk olma durumu }\end{array}$} & Evet & 14 \\
\hline & Hayır & 16 \\
\hline \multirow{4}{*}{$\begin{array}{l}\text { Çocukların özel gereksinim } \\
\text { durumu }\end{array}$} & Otizm & 6 \\
\hline & Hafif düzeyde zihinsel gerilik & 5 \\
\hline & İşitme engelli & 2 \\
\hline & DEHB & 1 \\
\hline
\end{tabular}

\section{Veri toplama süreci ve verilerin analizi}

Okul öncesi öğretmen adaylarının ve öğretmenlerinin kaynaştırma eğitimi hakkındaki görüşlerini belirlemek için bu araştırmada nitel araştırmalarda en sık kullanılan veri toplama aracı olan görüşme tekniği kullanılmıştır. Görüşmeler sırasında yarı yapılandırılmış görüşme tekniği tercih edilmiştir. Görüşme sırasında katılımcıların söylediklerinden hareketle yeni sorular ekleme, değiştirme ya da çıkarma yapmaya olanak vermesi ve derinlemesine bilgi sağlaması nedeniyle yarı yapılandırılmış görüşme tekniğinin kullanılması uygun bulunmuştur (Güler, Halıcıoğlu ve Taşğın, 2015). Yapılan alanyazın taramasından sonra hazırlanan görüşme soruları iki alan uzmanına inceletilmiş ve onlardan alınan görüşler doğrultusunda sorularda gerekli düzeltmeler ve eklemeler yapılmıştır.

Araştırmaya katılan katılımcılara görüşmenin amacı ve genel çerçevesi açılanarak görüşmelere başlanmıştır. Öncelikle araştırmaya katılmayı kabul eden öğretmenlerden randevu alınmıştır. Görüşmeler katılımcıların kendilerini rahat bir şekilde ifade etmeleri için kalabalık olmayan, dikkati dağıtacak uyarıcıların olmadığı ortamlarda gerçekleştirilmeye çalışılmıştır. Görüşmeler katılımcıların bilgisi dâhilinde ses kayıt cihazı ile kaydedilmiştir. Görüşmeciler görüşmeler sırasında katılımcılara düşünmeleri için zaman vermeye özen göstermiş, katılımcıların görüşlerini rahatça ifade edebilmelerini sağlamak için güvene ve empatiye dayalı bir etkileşim kurmaya dikkat etmişlerdir.

Araştırmada verilerin analizinde içerik analizi tekniği kullanılmıştır.

Araştırmada elde edilen veriler içerik analizi tekniği ile çözümlenmiştir. Analiz sırasında toplanan veriler birçok kez okunmuş ve anlam bakımından bütünü oluşturan bölümlere kodlar verilmiştir. Kodlamalar tamamlandıktan sonra belirlenen kodlar listelenmiş, kodlar arasındaki ortak 
noktalar belirlenmiş ve temalar oluşturulmuştur. Ardından kodlara ve temalara göre veriler düzenlenmiş ve birbirleri arasındaki ilişkiler ortaya koyularak veriler yorumlanmıştır.

\section{Bulgular}

Okul öncesi öğretmen ve öğretmen adaylarının kaynaştırmaya yönelik görüşlerinin karşılaştırılmasını amaçlayan bu araştırmanın bulgularına aşağıda yer verilmiştir.

\section{Okul öncesi ögretmen ve ögretmen adaylarının "Kaynaştırma nedir?” sorusuna verdikleri cevaplara ilişkin bulgular}

Okul öncesi öğretmen ve öğretmen adaylarının «Kaynaştırma nedir?» sorusuna verdikleri cevaplar Tablo 2'de verilmiştir.

Tablo 2

Kaynaştırma Nedir? Sorusuna İlişkin İçerik Analizi Sonuçları

\begin{tabular}{|c|c|c|c|}
\hline \multicolumn{2}{|l|}{ Öğretmenlere İlişkin Bulgular } & \multicolumn{2}{|l|}{ Öğretmen Adaylarına İlişkin Bulgular } \\
\hline Cevaplar & $\mathrm{f}$ & Cevaplar & $\mathrm{f}$ \\
\hline $\begin{array}{l}\text { Kaynaştırma türlerine göre verilen } \\
\text { cevaplar }\end{array}$ & & $\begin{array}{l}\text { Kaynaştırma türlerine göre verilen } \\
\text { cevaplar }\end{array}$ & \\
\hline $\begin{array}{l}\text { Özel gereksinimli çocukların genel eğitim } \\
\text { sınıflarında akranlarıyla eğitim alması }\end{array}$ & 18 & $\begin{array}{l}\text { Özel gereksinimli çocukların genel } \\
\text { eğitim sınıflarında akranlarıla } \\
\text { eğitim alması }\end{array}$ & 25 \\
\hline $\begin{array}{l}\text { Normal gelişim gösteren çocukların özel } \\
\text { gereksinimli çocuklarla birlikte eğitim } \\
\text { alması }\end{array}$ & 3 & $\begin{array}{l}\text { Özel gereksinimli çocukların günün } \\
\text { belli saatlerinde genel eğitim } \\
\text { sınıflarında eğitim alması }\end{array}$ & 2 \\
\hline $\begin{array}{l}\text { Özel gereksinimli çocukların alması } \\
\text { gereken eğitim }\end{array}$ & 2 & $\begin{array}{l}\text { Normal gelişim gösteren çocukların } \\
\text { özel gereksinimli çocuklarla birlikte } \\
\text { eğitim alması }\end{array}$ & 1 \\
\hline Toplam & 23 & Toplam & 28 \\
\hline $\begin{array}{l}\text { Sosyal gelişimi destekleme olarak verilen } \\
\text { cevaplar }\end{array}$ & & $\begin{array}{l}\text { Sosyal gelişimi destekleme olarak } \\
\text { verilen cevaplar }\end{array}$ & \\
\hline $\begin{array}{l}\text { Özel gereksinimli çocuğun sosyalleşmesi } \\
\text { ve diğer çocuklarla kaynaşması için } \\
\text { verilen eğitim }\end{array}$ & 4 & $\begin{array}{l}\text { Özel gereksinimli çocukların } \\
\text { toplumla kaynaşması için verilen } \\
\text { eğitim }\end{array}$ & 3 \\
\hline $\begin{array}{l}\text { Özel gereksinimli çocukların toplumla } \\
\text { kaynaşması için verilen eğitim }\end{array}$ & 3 & $\begin{array}{l}\text { Özel gereksinimli çocukların sosyal } \\
\text { gelişimlerini desteklemek amacıyla } \\
\text { yapılan eğitim programı }\end{array}$ & 1 \\
\hline $\begin{array}{l}\text { Normal gelişim gösteren çocukların } \\
\text { farkındalıklarını geliştirmek için verilen } \\
\text { eğitim }\end{array}$ & 1 & $\begin{array}{l}\text { Farkındalık, sosyal uyum gibi } \\
\text { kavramları normal gelişim gösteren } \\
\text { çocuklara benimsetmek }\end{array}$ & 1 \\
\hline Toplam & 8 & Toplam & 5 \\
\hline Diğer & & Diğer & \\
\hline $\begin{array}{l}\text { Özel gereksinimli çocuğun en az } \\
\text { kısıtlandığı ve en çok desteklendiği ortam }\end{array}$ & 3 & $\begin{array}{l}\text { Genel eğitim sınıflarında özel } \\
\text { gereksinimli çocuğun eğitim } \\
\text { almasını kolaylaştıracak her şey } \\
\text { Özel gereksinimli çocuk }\end{array}$ & 1 \\
\hline Toplam & 3 & Toplam & 2 \\
\hline
\end{tabular}

Okul öncesi öğretmen ve öğretmen adaylarının "Kaynaştırma nedir?" sorusuna verilen cevaplar incelendiğinde, cevapların kaynaştırma türüne göre, sosyal gelişim destekleme ve diğer olarak kategorileştiği görülmektedir. Bu konuyla ilgili olarak Ö.1, Ö.18, Ö.A 3 ve Ö. A. 21 şunları ifade etmiştir.

"Özel eğitime ihtiyacı olan çocukların akranlarıyla ĕgitim alabilmelerini sağlayan en az kısıtlayıcı sinıf ortamı diyebilirim (Ö.1)." 
"Özel gereksinimli çocukların akranlariyla birlikte normal sinuflarda eğitim almasl ve normal gelişim gösteren çocukların farkındalıklarını artırmayı amaçlayan eğitimdir (Ö.18).",

Özel gereksinimli çocukların normal akranlarıyla aynı ortamda bulunmasıdır. Bu sadece özel gereksinimli çocuklar için faydall bir eğitim değildir, normal gelişim gösteren çocuklar için de faydalıdır (Ö.A. 3)."

"Kaynaştırma; düz ve tersine kaynaşttrma olarak iki türlüdür. Düz kaynaştırmada gelişim düzeyi normal geliş̧im düzeyinin altında olan çocukların, geliş̧im düzeyi normal olan çocuklarla eğitim almasıdır. Tersine kaynaş̧tırma ise, düz kaynaştırmanın tam tersi, gelişim düzeyi normal çocukların geride olan çocuklarla eğitim almasıdır (Ö.A. 21)."

Okul öncesi öğretmen ve ögretmen adaylarının "Kaynaştırma ĕgitiminin avantajları nelerdir?" sorusuna verdikleri cevaplara ilişkin bulgular

Okul öncesi öğretmen ve öğretmen adaylarının « Kaynaştırma eğitiminin avantajları nelerdir?» sorusuna verdikleri cevaplar Tablo 3'te verilmiştir.

Tablo 3

Kaynaştırma Eğitiminin Avantajları Nelerdir? Sorusuna İlişkin İçerik Analizi Sonuçları

\begin{tabular}{|c|c|c|c|}
\hline Öğretmenlere İlişkin Bulgular & & Öğretmen Adaylarına İlişkin Bulgular & \\
\hline Cevaplar & $\mathrm{f}$ & Cevaplar & $\mathrm{f}$ \\
\hline $\begin{array}{l}\text { Özel gereksinimli çocuk açısından } \\
\text { avantajları }\end{array}$ & & $\begin{array}{l}\text { Özel gereksinimli çocuk açısından } \\
\text { avantajları }\end{array}$ & \\
\hline Sosyalleşme & 9 & Sosyalleşme & 16 \\
\hline Akran öğrenmesi & 8 & Akranlarıyla bir arada olma & 12 \\
\hline Daha az soyutlanmış hissetme & 7 & $\begin{array}{l}\text { Tüm gelişim alanlarının } \\
\text { desteklenmesi }\end{array}$ & 6 \\
\hline İletişim kurma becerisinin gelişimi & 5 & Topluma kazandırma & 6 \\
\hline Olumlu gelişim gösterme & 5 & Özgüven gelişimi & 6 \\
\hline Özgüven gelişimi & 4 & Benlik saygısının gelişimi & 4 \\
\hline Çevrenin kabulü & 4 & $\begin{array}{l}\text { Özel gereksinimli çocuğun kendisine } \\
\text { değer verildiğini anlaması }\end{array}$ & 4 \\
\hline $\begin{array}{l}\text { Yaşam koşullarına uyum sürecinin } \\
\text { hızlanması }\end{array}$ & 4 & Bağımsız hareket etme & 3 \\
\hline Benlik saygısının gelişimi & 3 & Olumlu gelişim gösterme & 2 \\
\hline İlgi ve yeteneklerin gelişimi & 3 & & \\
\hline $\begin{array}{l}\text { Kendi hızına ve kapasitesine göre } \\
\text { eğitim alma }\end{array}$ & 2 & & \\
\hline Toplam & 54 & Toplam & 59 \\
\hline $\begin{array}{l}\text { Normal gelişim gösteren çocuklar } \\
\text { açısından avantajları }\end{array}$ & & $\begin{array}{l}\text { Normal gelişim gösteren çocuk } \\
\text { açısından avantajları }\end{array}$ & \\
\hline $\begin{array}{l}\text { Özel gereksinimli çocukları yakından } \\
\text { tanıma ve kabul etme }\end{array}$ & 15 & Farkl11ıklara sayg1 & 18 \\
\hline Farklılıklara sayg1 & 13 & Empati kurma & 8 \\
\hline Hoşgörü ve yardımseverlik gelişimi & 10 & $\begin{array}{l}\text { Nasıl davranması gerektiğini } \\
\text { öğrenme }\end{array}$ & 8 \\
\hline Empati gelişimi & 9 & Olumlu tutum sergileme & 8 \\
\hline Sorumluluk gelişimi & 7 & Yardımseverlik & 6 \\
\hline $\begin{array}{l}\text { Arkadaşlarına yardım etmenin verdiği } \\
\text { mutluluk }\end{array}$ & 5 & $\begin{array}{l}\text { Özel gereksinimli çocukları } \\
\text { yakından tanıma }\end{array}$ & 5 \\
\hline Koşulsuz kabul etme & 3 & Akran eğitimi & 2 \\
\hline $\begin{array}{l}\text { Engellerin üstesinden gelme becerisinin } \\
\text { gelişimi }\end{array}$ & 3 & İletişim kurma & 2 \\
\hline Sosyalleşme & 2 & Sosyalleşme & 2 \\
\hline & & Sorumluluk alma & 1 \\
\hline Toplam & 67 & Toplam & 58 \\
\hline
\end{tabular}




\begin{tabular}{|c|c|c|c|}
\hline Öğretmen açısından avantajları & & Öğretmen açısından avantajları & \\
\hline Mesleki deneyimin artmasi & 17 & Mesleki deneyiminin artması & 15 \\
\hline Sınıf yönetimi becerilerinin gelişimi & 14 & Mesleki tatmin & 6 \\
\hline Duyarlılık gelişimi & 10 & Gelişimsel farkl1lıkları fark etmek & 6 \\
\hline Gelişimsel farklılıkları fark etmek & 8 & Özgüven kazanma & 3 \\
\hline Mesleki tatmin & 7 & Empati geliştirme & 2 \\
\hline Farklılıklara saygı gelişimi & 4 & Farkındalık yaratmak & 2 \\
\hline Farkındalık yaratma & 2 & İletişim becerisi & 2 \\
\hline Toplam & 62 & Toplam & 36 \\
\hline $\begin{array}{l}\text { Özel gereksinimli çocuğun ailesi } \\
\text { açısından avantajları }\end{array}$ & & $\begin{array}{l}\text { Özel gereksinimli çocuğun ailesi } \\
\text { açısından avantajları }\end{array}$ & \\
\hline Çocuğunu tanıma & 13 & Çocuğunun gelişimini takip etmek & 8 \\
\hline Mutlu olma & 11 & Mutlu olmak & 8 \\
\hline Sosyalleşme & 7 & Diğer ailelerle iletişim içinde olma & 4 \\
\hline Diğer ailelerle iletişim içinde olma & 7 & Öz farkındalık geliştirme & 3 \\
\hline \multirow[t]{3}{*}{ Ailenin yükünün azalması } & 4 & Ailenin bilinçlenmesi & 2 \\
\hline & & Ailenin yükünün azalması & 2 \\
\hline & & Aile içi iletişimin artması & 2 \\
\hline Toplam & 42 & Toplam & 31 \\
\hline $\begin{array}{l}\text { Normal gelişim çocuğun ailesi } \\
\text { açısından avantajları }\end{array}$ & & $\begin{array}{l}\text { Normal gelişim çocuğun ailesi } \\
\text { açısından avantajları }\end{array}$ & \\
\hline Farklılıklara sayg1 & 13 & Farklılıklara sayg1 & 11 \\
\hline Empati & 10 & Empati & 8 \\
\hline $\begin{array}{l}\text { Özel gereksinimli çocuklar hakkında } \\
\text { bilgi sahibi olma }\end{array}$ & 8 & Toplumsal farkındalık & 7 \\
\hline Aileler arası dayanışma & 7 & Aileler arası dayanışma & 4 \\
\hline $\begin{array}{l}\text { Özel gereksinimli çocuklara karş1 } \\
\text { duyarlı olma }\end{array}$ & 4 & & \\
\hline Toplam & 52 & Toplam & 30 \\
\hline
\end{tabular}

Tablo 3 incelendiğinde okul öncesi öğretmen ve öğretmen adaylarının kaynaştırma eğitiminin avantajlarına ilişkin cevaplarının özel gereksinimli çocuk açısından, normal gelişim gösteren çocuk açısından, öğretmen açısından, özel gereksinimli çocuğun ailesi açısından ve normal gelişim gösteren çocuğun ailesi açısından avantajları olarak kategorileştiği görülmektedir. Bu konuyla ilgili olarak Ö.13, Ö.27, Ö.A. 5 ve Ö.A. 18 şunları ifade etmiştir.

\footnotetext{
"Kaynaştırma eğitimiyle özel gereksinimli çocuklar arkadaşlarıyla sosyalleşirler, böylece daha az soyut hisseder. Sinıftaki diğer çocuklar farklllıklara saygı göstermeyi ögrenir. Öğretmen de gelişimsel farkllikkları ayırt eder, mesleki olarak tecrübesi artar (Ö.13)."

"Özel gereksinimli çocuklar akranlarıyla birlikte olarak öğrenir, arkadaşlarından yardım alır. Diğer çocuklar da özel gereksinimli arkadaşlarına empati duymayı ögrenirler (Ö.27).”
}

"Kaynaștırmanın bence hem özel gereksinimli çocuk hem normal gelişim gösteren çocuk hem de ögretmen açsindan faydaları vardır. Kaynaştırma, özel gereksinimli çocuğun gelișim alanlarının desteklenmesi açısından önemlidir, özellikle sosyal gelişsimi açısından faydalı olduğunu düşünüyorum. Normal gelişim gösteren çocuk empati kurmayl ve farklılıklara saygı göstermeyi öğrenir. Öğretmen ise kendini geliştirme şansina sahip olur (Ö.A. 5)."

"Özel gereksinimli çocuğun toplumdan uzaklaşmasını engeller ve çocuk sosyal açıdan kendini geliştirir. Ayrıca özgüveni açısından da faydalıdır. Ek olarak özel gereksinimli çocuğun ailesi açısından da önemlidir. Bu aileler genellikle toplum tarafindan hor görülüyormus gibi oluyor ve bu durumla tek başına savaşmak zorunda kalıyor. Kaynaştırma eğitimiyle ailenin yükünün azaldığın ve diğer ailelerle iletişim içine geçtiğini düşünüyorum. Bu durumda kaynaştırma diğer ailelerin de empati yeteneğini gelişstirir ve tüm aileler arasında dayanışma olur... (Ö.A.18). " 
Okul öncesi öğretmen ve ögretmen adaylarının "Kaynaştırma eğitiminin dezavantajları nelerdir?" sorusuna verdikleri cevaplara ilişkin bulgular

Okul öncesi öğretmen ve öğretmen adaylarının « Kaynaştırma eğitiminin dezavantajları nelerdir?» sorusuna verdikleri cevaplar Tablo 4'te verilmiştir.

Tablo 4

Kaynaştırma Eğitiminin Avantajları Nelerdir? Sorusuna İlişkin İçerik Analizi Sonuçları

\begin{tabular}{|c|c|c|c|}
\hline \multirow{2}{*}{$\begin{array}{l}\text { Ögretmenlere İlişkin Bulgular } \\
\text { Cevanlar }\end{array}$} & \multirow[b]{2}{*}{$\mathrm{f}$} & \multicolumn{2}{|l|}{ Öğretmen Adaylarına İlişkin Bulgular } \\
\hline & & Cevaplar & $\mathrm{f}$ \\
\hline $\begin{array}{l}\text { Özel gereksinimli çocuk açısından } \\
\text { dezavantajları }\end{array}$ & & $\begin{array}{l}\text { Özel gereksinimli çocuk açısından } \\
\text { dezavantajları }\end{array}$ & \\
\hline Özyeterlilik duygusunun zedelenmesi & 13 & Dişlanma & 13 \\
\hline Akranlarının kabul etmemesi & 12 & Yetersizlik hissi & 8 \\
\hline Özgüveninin zedelenmesi & 9 & Özgüvende düşüş & 3 \\
\hline $\begin{array}{l}\text { Çeşitli duygusal tepkiler sergileme (üzülme, } \\
\text { sinirlenme, içine kapanma) }\end{array}$ & 8 & İçine kapanma & 3 \\
\hline Diğer çocukların alay konusu olma & 7 & Duygusal istismara uğrama & 3 \\
\hline Fiziksel tehlikelerle karşı karşıya gelme & 3 & Kiskanma & 2 \\
\hline Sınıftaki olumsuzluklardan suçlanma & 3 & & \\
\hline Toplam & 55 & Toplam & 32 \\
\hline $\begin{array}{l}\text { Normal gelişim gösteren çocuk açısından } \\
\text { dezavantajları }\end{array}$ & & $\begin{array}{l}\text { Normal gelişim gösteren çocuk açısından } \\
\text { dezavantajları }\end{array}$ & \\
\hline SSiddete maruz kalma & 11 & Uyum problemleri yaşama & 9 \\
\hline Özel gereksinimli çocuklara üzülme & 10 & Kiskançlık & 5 \\
\hline Öğretmenini kıskanma & 7 & $\begin{array}{l}\text { Özel gereksinimli çocuğun öfke nöbetleri } \\
\text { sebebiyle yaralanma }\end{array}$ & 3 \\
\hline Özel gereksinimli çocuktan korkma & 6 & Acıma duygusu & 2 \\
\hline Uyum sorunları yaşama & 3 & Okula gelmek istememe & 2 \\
\hline Toplam & 38 & Toplam & 21 \\
\hline Öğretmen açısından dezavantajları & & Öğretmen açısından dezavantajları & \\
\hline Sinıf yönetimi sağlamada zorlanma & 21 & Sınıf yönetimini sağlamada zorlanma & 17 \\
\hline Yeterli bilgi ve beceri eksikliği & 17 & Uyarlama yapmakta zorlanma & 6 \\
\hline $\begin{array}{l}\text { Özel gereksinimli ya da diğer çocuklara } \\
\text { yeterki kadar zaman ayıramama kaygısı }\end{array}$ & 14 & $\begin{array}{l}\text { Özel gereksinimli çocuğun etkinliklere } \\
\text { katılımında zorlanma }\end{array}$ & 5 \\
\hline İş yükünün artması & 10 & Diğer çocuklarla ilgilenmede kısıtllılık & 4 \\
\hline Özel gereksinimli çocuğu tanımada zorlanma & 7 & $\begin{array}{l}\text { Özel gereksinimli çocuk için kişisel } \\
\text { zamanından daha fazla zaman ayırma }\end{array}$ & 3 \\
\hline Motivasyonun düşmesi & 3 & & \\
\hline Toplam & 72 & Toplam & 35 \\
\hline $\begin{array}{l}\text { Özel gereksinimli çocuğun ailesi açısından } \\
\text { dezavantajları }\end{array}$ & & $\begin{array}{l}\text { Özel gereksinimli çocuğun ailesi açısından } \\
\text { dezavantajları }\end{array}$ & \\
\hline $\begin{array}{l}\text { Çocuğunun durumundan dolayı üzülme ya da } \\
\text { utanma }\end{array}$ & 12 & $\begin{array}{l}\text { Diğer çocuklarla kıyaslayıp çocuklarının } \\
\text { yetersizliğine üzülme }\end{array}$ & 6 \\
\hline Çocuğunu diğer çocuklarla kiyaslama & 6 & $\begin{array}{l}\text { Kaynaştırmadaki aksaklıklarla nedeniyle } \\
\text { çocuğun okula gitmek istememesi }\end{array}$ & 3 \\
\hline Önyargılarla göğüs germe & 5 & Öğretmenle sorun yaşama & 3 \\
\hline Çocuğuna daha çok zaman ayırmaya çalışma & 3 & Diğer çocukların aileleriyle problem yaşama & 2 \\
\hline & & Maddi yetersizlik & 2 \\
\hline & & Tedirgin olma & 2 \\
\hline Toplam & 26 & Toplam & 18 \\
\hline $\begin{array}{l}\text { Normal gelişim çocuğun ailesi açısından } \\
\text { dezavantajları }\end{array}$ & & $\begin{array}{l}\text { Normal gelişim çocuğun ailesi açısından } \\
\text { dezavantajları }\end{array}$ & \\
\hline $\begin{array}{l}\text { Çocuğunun eğitimi ve gelişimi hakkında } \\
\text { kaygılanma }\end{array}$ & 14 & Çocuğu için endişe duyma & 12 \\
\hline Çocuğunu okula göndermekte zorlanma & 4 & Rahatsızlık duyma & 4 \\
\hline & & Çocuğunu okula göndermekte zorlanma & 2 \\
\hline Toplam & 18 & Toplam & 18 \\
\hline
\end{tabular}


Tablo4 incelendiğinde okul öncesi öğretmen ve öğretmen adaylarının kaynaştırma eğitiminin dezavantajlarına ilişkin cevaplarının özel gereksinimli çocuk açısından, normal gelişim gösteren çocuk açısından, öğretmen açısından, özel gereksinimli çocuğun ailesi açısından ve normal gelişim gösteren çocuğun ailesi açısından zararları olarak kategorileştiği görülmektedir. Bu konuyla ilgili olarak Ö.5, Ö.28, Ö.A.2 ve Ö.A. 10 şunları ifade etmiştir.

"Kendini yetersiz hissedebilir. Diğer arkadaşlarına yetişmeye çalıșıp başaramama duygusu onun özyeterlilik duygularını zedeleyebilir. Kendine olan güvenini sarsıcı durumlar yaşayabilir (Ö.5). ”

“Özel gereksinimli çocuk akranları tarafindan kabul görmeyebilir. Ayrıca öğretmenin sınıf yönetimini să̆lamada ciddi sıkıntılar yaşayacă̆ını düşünüyorum (Ö.28). ”

"Özel gereksinimli çocuk sınıfta dışlanabilir. Bu durum ailesinin de umutsuzluğa düşmesine yol açabilir. Öğretmen sinıf yönetiminde zorlanabilir ve günlük akışta aksamalar yaşanabilir (Ö.A. 2).”,

"Akranlarıyla aynı ortama gelen özel gereksinimli çocuk akranlarının yapabildiği etkinlikleri kendisinin yapamadı̆̆ını görünce kendisini yetersiz görebilir. Bu durumu gören normal gelişim gösteren çocuklar hem psikolojik olarak etkilenebilir hem de özel gereksinimli çocuğa acıma duygusu geliştirebilir. Bu durumu ailesine yansitabilir (Ö.A.10)."

Okul öncesi öğretmen ve öğretmen adaylarının "Hangi özel gereksinim grupları kaynaştırmaya alınabilir?" sorusuna verdikleri cevaplara ilişkin bulgular

Okul öncesi öğretmen ve öğretmen adaylarının «Hangi özel gereksinim grupları kaynaştırmaya alınabilir?» sorusuna verdikleri cevaplar Tablo 5 'te verilmiştir.

Tablo 5

Hangi Özel Gereksinim Grupları Kaynaştırmaya Alınabilir? Sorusuna İlişkin İçerik Analizi Sonuçları

\begin{tabular}{|c|c|c|c|}
\hline Öğretmenlere İlişkin Bulgular & & Öğretmen Adaylarına İlişkin Bulgulaı & \\
\hline Cevaplar & $\mathrm{f}$ & Cevaplar & $\mathrm{f}$ \\
\hline Rastlanma sıklığı yüksek olan gruplar & & $\begin{array}{l}\begin{array}{l}\text { Rastlanma } \\
\text { gruplar }\end{array} \\
\text { sıklı̆̆ }\end{array}$ & \\
\hline $\begin{array}{l}\text { Dikkat eksikliği ve } \\
\text { bozukluğu olan çocuklar }\end{array}$ & 15 & $\begin{array}{l}\text { Dikkat eksikliği ve hiperaktivite } \\
\text { bozukluğu olan çocuklar }\end{array}$ & 9 \\
\hline $\begin{array}{l}\text { Hafif düzeyde zihinsel yetersizliği olan } \\
\text { çocuklar }\end{array}$ & 11 & $\begin{array}{l}\text { Hafif düzeyde zihinsel yetersizliği } \\
\text { olan çocuklar }\end{array}$ & 6 \\
\hline Üstün yetenekli çocuklar & 4 & Üstün yetenekli çocuklar & 5 \\
\hline Özgül öğrenme güçlüğü olan çocuklar & 1 & $\begin{array}{l}\text { Özgül öğrenme güçlüğü olan } \\
\text { çocuklar }\end{array}$ & 1 \\
\hline Toplam & 31 & Toplam & 21 \\
\hline $\begin{array}{l}\text { Rastlanma s1klığı düşük olan gruplar } \\
\text { İșitme yetersizliği olan çocuklar }\end{array}$ & 9 & $\begin{array}{l}\text { Rastlanma s1klığı düşük olan gruplar } \\
\text { İșitme yetersizliği olan çocuklar }\end{array}$ & 10 \\
\hline Ortopedik yetersizliği olan çocuklar & 8 & Ortopedik yetersizliği olan çocuklar & 10 \\
\hline Görme yetersizliği olan çocuklar & 6 & Görme yetersizliği olan çocuklar & 8 \\
\hline Otizmli çocuklar & 6 & Otizmli çocuklar & 8 \\
\hline Dil ve konuşma bozukluğu & 4 & Sağlık problemleri olan çocuklar & 5 \\
\hline & & $\begin{array}{l}\text { Çoklu yetersizliği olan çocuklar ( } 2 \\
\text { yetersizliği varsa) }\end{array}$ & 2 \\
\hline Toplam & 33 & Toplam & 43 \\
\hline Tüm gruplar kaynaştırmaya alınmalıdır & 7 & $\begin{array}{l}\text { Tüm gruplar } \\
\text { alınmalıdır }\end{array}$ & 8 \\
\hline & & $\begin{array}{l}\text { Hiçbir grup } \\
\text { alınmamalıdır }\end{array}$ & 1 \\
\hline
\end{tabular}

Tablo 5 incelendiğinde okul öncesi öğretmen ve öğretmen adaylarının hangi özel gereksinim gruplarının kaynaştırmaya alınması gerektiğine dair cevaplarının rastlanma sıklığı yüksek olan gruplar 
ve rastlanma sıklığı düşük olan gruplar olarak kategorileştiği görülmektedir. Ayrıca sekiz öğretmen adayı ve yedi öğretmen tüm grupların kaynaştırmaya alınması gerektiğini düşünürken bir öğretmen adayı hiçbir özel gereksinim grubunun kaynaştırmaya alınmaması gerektiğini düşünmektedir. $\mathrm{Bu}$ konuyla ilgili olarak Ö.4, Ö.22, Ö.A. 7 ve Ö.A. 22 şunları ifade etmiştir.

\begin{abstract}
"Aslinda tüm özel gereksinim durumlarl seviyelerine göre kaynaştırmaya dâhil edilmelidir. Dil ve konuşma bozukluğu- işitme engelli çocuklar kesinlikle kaynaştırmaya alınmal. Özellikle okul öncesi dönemde kritik dönemde olan dil gelişimi kelime artışlarına ve telaffuzlarına yadsinamaz derecede katkr sağlar. Akademik ve sosyal becerileri akranları ile etkileşime girdikleri için ilerleyecek ve kendilerine yetebilir olmalar yolunda önemli adımlar atmalar sağlanmış olacağ i için zihinsel engelli çocuklar da alınmalı diye düşünüyorum. Son olarak görme engelli çocuklar kaynaştırmaya alınırsa toplum içine girdiklerinde çevrelerini kontrol etmede daha yetkin bir birey haline gelmeleri sağlanır $(\ddot{O} .4)$."
\end{abstract}

"Dil ve konuşma bozukluğu, zihinsel engel, ögrenme güçlüğ̈̈, duygu durum bozukluğu, görme güçlüğü, işitme güçlüğü, bedensel engel, üstün zekâ, dikkat eksikliği, otizm gibi gruplar kaynaştırmaya alınır. Çünkü amaç onların kendi yeterliliklerinin farkına varmasını sağlamaktır (Ö.22)."

"İşitme yetersizliği, görme yetersizliği, zihinsel yetersizliği, dil ve konuşma bozukluğu, özgül öğrenme güçlüğü, otizm... Kısaca tüm yetersizlik gruplarının kaynaşttrmaya alınması gerektiğini düşünüyorum (Ö.A.7)."

"İşitme engelli ve down sendromlu çocukların normal gelişim gösteren çocuklara uyum sağlamada diğer özel gereksinim gruplarına nazaran daha başarılı olacaklarını düşünüyorum (Ö.A.22).”

Okul öncesi ögretmen ve öğretmen adaylarının "Hangi özel gereksinim grupları kaynaştırmaya alınmamalıdır?" sorusuna verdikleri cevaplara ilişkin bulgular

Okul öncesi öğretmen ve öğretmen adaylarının «Hangi özel gereksinim grupları kaynaştırmaya alınmamalıdır?» sorusuna verdikleri cevaplar Tablo 6'da verilmiştir.

Tablo 6

Hangi Özel Gereksinim Grupları Kaynaştırmaya Alınmamalıdır? Sorusuna İlişkin İçerik Analizi Sonuçları

\begin{tabular}{|c|c|c|c|}
\hline Öğretmenlere İlișkin Bulgular & & Öğretmen Adaylarına İlişkin Bulgular & \\
\hline Cevaplar & $\mathrm{f}$ & Cevaplar & $\mathrm{f}$ \\
\hline Rastlanma s1klığı yüksek olan gruplar & & $\begin{array}{l}\text { Rastlanma sıklığ } \quad \text { yüksek olan } \\
\text { gruplar }\end{array}$ & \\
\hline $\begin{array}{l}\text { Zihinsel yetersizliği olan çocuklar } \\
\text { (ağır düzeyde) }\end{array}$ & 7 & $\begin{array}{l}\text { Zihinsel yetersizliği olan çocuklar } \\
\text { (ağır) } \\
\text { Dikkat eksikliği ve hiperaktivite } \\
\text { bozukluğu olan çocuklar }\end{array}$ & 6 \\
\hline Toplam & 7 & Toplam & 7 \\
\hline $\begin{array}{l}\text { Rastlanma sıklığ düşük olan gruplar } \\
\text { Ağır ortopedik yetersizliği olan }\end{array}$ & 3 & $\begin{array}{l}\text { Rastlanma sıklığı düşük olan gruplar } \\
\text { İşitme yetersizliği olan çocuklar }\end{array}$ & 3 \\
\hline
\end{tabular}
çocuklar

Otizmli çocuklar 2

Sağllk problemleri olan çocuklar $\quad 2$

Çoklu yetersizliği olan çocuklar $\quad 1$

Görme yetersizliği olan çocuklar $\quad 1$

Ağır ortopedik yetersizliği olan 4 çocuklar

Görme yetersizliği olan çocuklar $\quad 4$

Otizmli çocuklar 1

$\begin{array}{ll}\text { Sağlık problemleri olan çocuklar } & \\ \text { Çoklu yetersizliği olan çocuklar } & 5\end{array}$

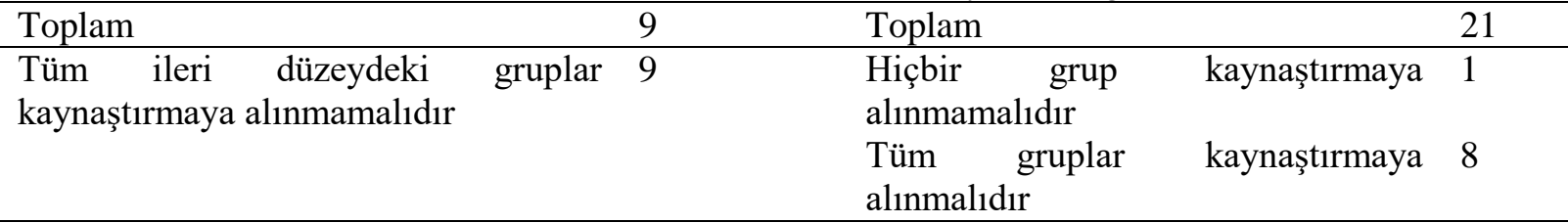


Tablo 6 incelendiğinde okul öncesi öğretmen ve öğretmen adaylarının hangi özel gereksinim gruplarının kaynaştırmaya alınmaması gerektiğine dair cevaplarının rastlanma sıklığı yüksek olan gruplar ve rastlanma sıklı̆g düşük olan gruplar olarak kategorileştiği görülmektedir. Ayrıca sekiz ögretmen adayı tüm grupların kaynaştırmaya alınması gerektiğini düşünürken 1 öğretmen adayı hiçbir özel gereksinim grubunun kaynaştırmaya alınmaması gerektiğini; 9 öğretmen ise tüm ileri düzeydeki grupların kaynaştırmaya alınmaması gerektiğini düşünmektedir. Bu konuyla ilgili olarak Ö.14, Ö.29, Ö.A.22 ve Ö.A. 30 şunları ifade etmiştir.

"Ağgr düzeyde seyreden; otizm, zihinsel engellilik, down sendromu, beyin felci gibi kendini kontrol etmeleri çok zor olan çocuklar engel türleri ile özdeş gruplarda eğitilmelidir. Hatta mümkünse bireysel ya da küçük gruplar halinde ögretim görmelidirler (Ö.14)."

"Ağır derecede zihinsel yetersizliği olanlar ve otizmli çocuklar alınmamalı bence (Ö.29)."

"İşitme engelli ve down sendromu dışındaki grupların alınmaması gerektiğini düşünüyorum, özellikle zihinsel engelli ve görme engelli çocuklara uyarlama yapmanın oldukça sıkıntıll ve zor olabileceğini düşünüyorum (Ö.A.22)."

"Bence hiçbir grup kaynaştırmaya alınmamalıdır. Özel eğitim slnıflarının onlar için daha faydalı olacăğıı düşünüyorum (Ö.A.30)."

Okul öncesi ögrretmen ve ögretmen adaylarının "Sinıfınızda kaynaştırma uygulamalarının başarılı olabilmesi için neler yapabilirsiniz?” sorusuna verdikleri cevaplara iliş̧kin bulgular

Okul öncesi öğretmen ve öğretmen adaylarının «Sınıfınızda kaynaştırma uygulamalarının başarılı olabilmesi için neler yapabilirsiniz?» sorusuna verdikleri cevaplar Tablo 7'de verilmiştir.

Tablo 7

Sınıfınızda Kaynaştırma Uygulamalarının Başarılı Olabilmesi İçin Neler Yapabilirsiniz? Sorusuna İlişkin İçerik Analizi Sonuçları

\begin{tabular}{|c|c|c|c|}
\hline Öğretmenlere İlişkin Bulgular & & Öğretmen Adaylarına İlișkin Bulgular & \\
\hline Cevaplar & $\mathrm{f}$ & Cevaplar & $\mathrm{f}$ \\
\hline $\begin{array}{llll}\text { Özel gereksinimli } & \text { çocukla } & \text { ilgili } \\
\text { yapılabilecekler }\end{array}$ & & $\begin{array}{l}\text { Özel gereksinimli çocukla ilgili } \\
\text { yapilabilecekler }\end{array}$ & \\
\hline Uygun etkinlikler hazırlama & 7 & Uygun etkinlikler hazırlama & 16 \\
\hline Çocuğu iyi tanıma & 5 & Empati kurma & 7 \\
\hline & & Özel olarak ilgilenme & 5 \\
\hline & & Sınıfı önceden hazırlama & 5 \\
\hline & & Özel öğretim yöntemleri kullanma & 3 \\
\hline & & Göz teması kurma & 1 \\
\hline Toplam & 12 & Toplam & 37 \\
\hline $\begin{array}{l}\text { Normal gelişim gösteren çocuk ve ailesi } \\
\text { için yapabilecekler }\end{array}$ & & $\begin{array}{l}\text { Normal gelişim gösteren çocuk ve } \\
\text { ailesi için yapabilecekler }\end{array}$ & \\
\hline $\begin{array}{l}\text { Öğrencileri ve aileleri özel gereksinimli } \\
\text { cocuk hakkında bilgilendirme }\end{array}$ & 14 & Çocuğun önyargılarını kırma & 13 \\
\hline $\begin{array}{l}\text { Çocukların duygularını ifade } \\
\text { edebilecekleri etkinliklere ver verme }\end{array}$ & 8 & Aileleri bilgilendirme & 5 \\
\hline Empati gelişimini destekleme & 6 & Ailelerin önyargılarını kırma & 4 \\
\hline Toplam & 28 & Toplam & 22 \\
\hline $\begin{array}{lll}\text { Öğretmenin } & \text { kendisiyle } & \text { ilgili } \\
\text { yapabilecekleri } & & \end{array}$ & & $\begin{array}{l}\text { Öğretmenin } \\
\text { yapabilecekleri }\end{array}$ & \\
\hline Yardımcı personel isteğinde bulunma & 11 & Azimli olma & 4 \\
\hline $\begin{array}{l}\text { Özel eğitim öğretmenleri ile işbirliği } \\
\text { yapma }\end{array}$ & 7 & Kendini geliştirme & 2 \\
\hline Sinıfta düzenlemeler yapma & 7 & & \\
\hline Kendini geliştirme & 5 & & \\
\hline Toplam & 30 & Toplam & 6 \\
\hline
\end{tabular}




\begin{tabular}{|c|c|c|c|}
\hline \multicolumn{2}{|l|}{$\begin{array}{l}\text { Özel gereksinimli çocuğun ailesiyle } \\
\text { ilgili yapılabilecekler }\end{array}$} & \multicolumn{2}{|c|}{$\begin{array}{l}\text { Özel gereksinimli çocuğun ailesiyle } \\
\text { ilgili yapilabilecekler }\end{array}$} \\
\hline $\begin{array}{l}\text { Düzenli olarak görüşme ve iletişim } \\
\text { kurma }\end{array}$ & 11 & Seminler verme & 3 \\
\hline $\begin{array}{l}\text { Karş1laşabilecekleri hakkında } \\
\text { verme }\end{array}$ & 5 & İletişim içinde olma & 2 \\
\hline Toplam & 16 & Toplam & 5 \\
\hline
\end{tabular}

Tablo 7 incelendiğinde okul öncesi öğretmen ve öğretmen adaylarının kaynaştırma eğitiminin başarılı olabilmesi için yapabileceklerine dair verdikleri cevapların özel gereksinimli çocuk açısından, normal gelişim gösteren çocuk açısından, öğretmen açısından, özel gereksinimli çocuğun ailesi açısından ve normal gelişim gösteren çocuğun ailesi açısından yapılabilecekler olarak kategorileştiği görülmektedir. Bu konuyla ilgili olarak Ö.2, Ö.16, Ö.A.13 ve Ö.A.25 şunları ifade etmiştir.

\begin{abstract}
"Kaynaştırma öğrencisi sinıfima gelmeden önce slnfftaki çocuklarl, aileleri bu duruma hazırlayıcı etkinlikler düzenlerim. Kaynaşttrma öğrencim ve ailesi ile daha önceden görüsüüp eğitim sürecinde neler yapacă̆ız, nelerle karşılaşacağız konuşurum. Kaynaştırma öğrencim geldiğinde onun diğer arkadaşları ile özdeşleşmesi ve grup içinde farklllı̆̆ından dolayı dışlanmaması için elimden gelen her türlü faaliyeti yaparım. Bir problem yaşanırsa problem kaynağını tespit eder hangi konudaysa onu çözmek için etkinlikler yaparım. Genellikle oyunlarla bunu çözmeye çallşır; bu nedenle drama uygulamalarına bolca yer veririm (Ö.2)."
\end{abstract}

"Çocuklara empati kazandırmaya çallşırım. Etkinliklerimi seçerken gereksinim duyan çocukları da etkinliğe katacak şekilde oluştururum. Sinıf düzenlemelerimi bu doğrultuda yaparım. Kendimi geliştirmek için araştırmalar yaparım (Ö.16)."

"Özel gereksinimli çocuk okula gelmeden önce sinıftaki çocukları, aileleri, okuldaki personeli çocuk hakkında bilgilendirebiliriz. Ayrıca sınıf ortamını da çocuğa uygun şekilde düzenleyebiliriz (Ö.A. 13)."

"Fiziki şartları düzenlerim, yöntemde uyarlamalara yer veririm, çocukları ve yönetimi bu uygulamaların gerekliliğine ikna edip yardımcı olmalarını sağlarım. Son olarak aileyi bu uygulamalarda sorumluluk alırlarsa başarılı olacağımıza ikna ederim (Ö.A.25)."

Okul öncesi ögretmen ve ögretmen adaylarının "Kaynaştırma ögrencisi genel eğitim sinıflarında haftada ne kadar süreyle eğitim almalıdır?" sorusuna verdikleri cevaplara ilişkin bulgular

Okul öncesi öğretmen ve öğretmen adaylarının « Kaynaştırma öğrencisi genel eğitim sınıflarında haftada ne kadar süreyle eğitim almalıdır?» sorusuna verdikleri cevaplar Tablo 8'de verilmiştir.

Tablo 8

Kaynaştırma öğrencisi genel eğitim sınıflarında haftada ne kadar süreyle eğitim almalıdır? Sorusuna İlişkin İçerik Analizi Sonuçları

\begin{tabular}{llll}
\hline Öğretmenlere İlişkin Bulgular & & Öğretmen Adaylarına İlişkin Bulgular & \\
Cevaplar & $\mathrm{f}$ & Cevaplar & $\mathrm{f}$ \\
\hline Engel derecesine göre değişir & 12 & Haftada 3 gün & 11 \\
Her gün & 9 & Engel derecesine göre değişir & 8 \\
3 gün & 4 & Her gün & 7 \\
2 gün & 3 & Haftada 2-3 gün & 2 \\
Haftada 5 gün sadece 2-3 saat & 1 & Hiçbir fikrim yok & 1 \\
Bilmiyorum & 1 & Gelmemeli & 1 \\
\hline Toplam & 30 & Toplam & 30 \\
\hline
\end{tabular}

Bu konuyla ilgili olarak Ö.11, Ö.21, Ö.A.1 ve Ö.A. 11 şunları ifade etmiştir.

"Özel gereksinimli çocuğun yetersizlik seviyesine göre bu saat değişiklik gösterir. İsterim ki tüm eğitim saati boyunca sinifta yer alsın. Bu onun hem özgüvenini artırır. Hem de kendini gruba dâhil hissetmesini kolaylaştırır. Akranları da aynı şekilde arkadaşlarını kendilerinden farksı görürler (Ö.11)." 
"Bence haftanın 5 günü de eğitime gelmelidir. Bir devam olmalıdır. Fakat okulda bulunacă̆ süre gereksinim durumuna göre farklılı gösterebilir. Çocuk devamlı gelirse toplumda kabul görme durumu olumlu yönde artar ve sosyalleşmesi hızlanır. Akran iletişimi olumlu yönde artar (Ö.21)."

"Bu durum çocuğun engel derecesine göre değişir, haftada iki gün de olabilir devamlı sınıfta da... (Ö.A.1)."

“Normal gelişim gösteren çocuklar gibi sürekli eğitim almalıdır (Ö.A.11).”

Okul öncesi ögrretmen ve öğretmen adaylarının "Okul öncesi eğitimde kaynaştırma önemlidir; çünkü ..." sorusuna verdikleri cevaplara ilişkin bulgular

Okul öncesi öğretmen ve öğretmen adaylarının «Okul öncesi eğitimde kaynaştırma önemlidir; çünkü ...» sorusuna verdikleri cevaplar Tablo 9' da verilmiştir.

Tablo 9

Okul öncesi eğitimde kaynaştırma önemlidir; çünkü ... Sorusuna İlişkin İçerik Analizi Sonuçları

\begin{tabular}{|c|c|c|c|}
\hline \multicolumn{2}{|l|}{ Öğretmenlere İlişkin Bulgular } & \multicolumn{2}{|l|}{ Öğretmen Adaylarına İlişkin Bulgular } \\
\hline Cevaplar & $\mathrm{f}$ & Cevaplar & $\mathrm{f}$ \\
\hline Eğitim ve firsat eşitliği & & Eğitim ve firsat eşitliği & \\
\hline Eğitim hakk1 & 4 & Eğitim hakkı & 10 \\
\hline Fursat eşitliği & 3 & Firsat eşitliği & 2 \\
\hline Toplam & 7 & Toplam & 12 \\
\hline Özel gereksinimli çocuk için önemi & & Özel gereksinimli çocuk için önemi & \\
\hline Gelişim alanlarının desteklenmesi & 15 & Topluma kazandırma & 12 \\
\hline Topluma kazandırma & 11 & Sosyal gelişim & 3 \\
\hline Akranlarıyla birlikte olma & 8 & Her çocuk önemlidir & 3 \\
\hline $\begin{array}{l}\text { Rahat ve kendini ifade edebileceği } \\
\text { bir ortam sunma }\end{array}$ & 7 & Akranlarıyla birlikte olma & 2 \\
\hline İlkokula hazırlanma & 2 & & \\
\hline Toplam & 43 & Toplam & 20 \\
\hline $\begin{array}{l}\text { Normal gelişim gösteren çocuk için } \\
\text { önemi }\end{array}$ & & $\begin{array}{l}\text { Normal gelişim gösteren çocuk için } \\
\text { önemi }\end{array}$ & \\
\hline Bireysel farkl11ıkların kabul etme & 7 & Sosyal gelişim & 3 \\
\hline Sosyal gelişim & 5 & Farkındalık kazandırma & 2 \\
\hline Farkındalık kazandırma & 4 & & \\
\hline Toplam & 16 & Toplam & 5 \\
\hline
\end{tabular}

Tablo 9 incelendiğinde okul öncesi öğretmen ve öğretmen adaylarının verdikleri cevapların eğitim ve firsat eşitliği, özel gereksinimli çocuk için önemi ve normal gelişim gösteren çocuk için önemi olarak kategorileştiği görülmektedir. Bu konuyla ilgili olarak Ö.8, Ö.26, Ö.A 3 ve Ö.A. 17 şunları ifade etmiştir.

“... erken yaşta özel gereksinimli çocukları topluma kazandırmak, bu gereksinimlerinden dolayı dışlanmalarını engellemek için gereklidir (Ö.8).”

“... her çocuğun akranlarıla birlikte ĕ̌itim görmesi onların hakkıdır (Ö.26).”

“... her çocuğun kabul görmeye, ötelenmemeye, bizden biri olduğunun yani diğer çocukların farkındalık kazanmasına ihtiyaç vardır (Ö.A.3).”

“... akranlarılla ilişki kurmak, bu firsatı yakalamak, ayrıştırllmamak, ötekileştirilmemek her çocuğun her bireyin hakkıdır... (Ö.A.17).,

Tartışma, Sonuç ve Öneriler

İlk başladığı y1llardan itibaren sürekli gelişme kaydeden kaynaştırma, günümüzde özel gereksinimli çocukların genel eğitim sınıflarında öğretmenler tarafından eğitilmesi olarak tanımlanmaktadır 
(Mastropieri ve Scruguss, 2015). Kaynaştırmanın en temel amacı, özel gereksinime ihtiyacı olan çocukların akranlarından ve toplumdan soyutlanmasını önlemek ve onların kendilerini toplumun bir parçaları olarak görmelerini sağlamaktır. Özel gereksinimli çocukların okul öncesi eğitimden itibaren genel eğitim sınıflarına yerleştirilmesi bu sebeple çok önemli bir yere sahiptir. Ayrıca öğretmenlerin kaynaştırmaya yönelik tutumları, eğitim durumları kaynaştırmayı etkileyen faktörlerdendir (Salend, 1998). Bu nedenle tüm öğretmen ve adaylarının kaynaştırmaya yönelik bilgi sahibi olmaları ve lisans eğitimlerinden itibaren olumlu tutum geliştirmeleri son derece önemlidir.

$\mathrm{Bu}$ çalışmada okul öncesi öğretmenleri ve öğretmen adaylarının kaynaştırmaya yönelik görüşlerini karşılaştırmak amaçlanmıştır. Bu amaçla 30 okul öncesi öğretmeni ve 30 okul öncesi öğretmen adayıyla yarı yapılandırılmış görüşmeler yapılmıştır. Yapılan çalışma sonucunda öğretmen adaylarının kaynaştırmayı çoğunlukla genel eğitim sınıflarında özel gereksinimli çocuğun akranlarıyla eğitim alması olarak tanımladıkları, öğretmenlerin de buna benzer tanımlar yaptığı görülmüştür. $\mathrm{Bu}$ çalışmanın sonuçlarıyla paralel olarak Rakap ve Kaczmarek (2010) tarafından yapılan çalışmada da öğretmenlerin kaynaştırmayı özel gereksinimli çocukların genel eğitim sınıflarında eğitim alması olarak tanımladıkları belirlenmiştir. Benzer şekilde Stoiber, Gettinger ve Goetz (1998) tarafindan yapılan çalışmada da öğretmenlerin kaynaştırmayı genel eğitim sınıflarında özel gereksinimli çocukların eğitim almaları olarak tanımladıkları belirlenmiştir. Bununla birlikte öğretmenler ve öğretmen adaylarının tersine kaynaştırmayla ilgili bilgi sahibi olmaları dikkat çekici bir bulgu olarak karşımıza çıkmaktadır. Tersine kaynaştırmada, "yetersizlikleri olmayan bireyler istekleri doğrultusunda özellikle okul öncesi eğitimde, çevrelerindeki kaynaştırma uygulaması yapılan özel eğitim okullarında açılacak sınıflara kayıt yaptırabilirler." (Aral, 2010, s. 56).

Okul öncesi öğretmenleri ve öğretmen adayları kaynaştırmayı birçok açıdan avantajlı bulduklarını belirtmişlerdir. Öğretmenler ve öğretmen adayları kaynaştırmanın özel gereksinimli çocuk, normal gelişim gösteren çocuk, özel gereksinimli çocuğun ailesi ve diğer çocukların aileleri ve kendileri açısından avantajlı bulduklarını belirtmişlerdir. Öğretmenler ve öğretmen adayları, özel gereksinimli çocuğun kaynaştırma eğitimiyle sosyalleşmesinin artacağını, tüm gelişim alanlarının destekleneceğini ve akranlarıyla birlikte olmasının faydalı olacağını düşünmekte, normal gelişim gösteren çocukların empati duygularının gelişeceklerini ve farklılıklara saygı duymayı öğreneceklerini düşünmektedirler. Bu bulgulara paralel olarak Artan ve Uyanık Balat (2003) tarafindan yapılan çalışmada okul öncesi öğretmenlerinin kaynaştırmayı özel gereksinimli çocukların sosyalleşmesi ve gelişim alanlarının desteklenmesi açısından faydalı buldukları, normal gelişim gösteren çocukların da farklılıklara saygı duymayı öğrenmeleri açısından kaynaştırmayı önemli buldukları belirlenmiştir. Gök ve Erbaş (2011) tarafindan yapılan çalışmada da bu sonuçlara paralel olarak okul öncesi öğretmenlerinin, özel gereksinimli çocukların sosyal gelişimlerinin desteklendiği ve topluma kazandırılması sebebiyle kaynaştırma eğitimini yararlı buldukları belirlenmiştir. Batu, Kırcaali-iftar ve Uzuner (2004) tarafından yapılan çalışmada öğretmenlerin kaynaştırma eğitimini sosyal gelişim açısından faydalı buldukları belirlenmiştir.

Araştırmadan elde edilen diğer bir bulgu, okul öncesi öğretmen ve öğretmen adayları kaynaştırma eğitiminin faydalarının yanında tüm gruplar için bir takım zararları bulunabileceğini belirtmiş olmalarıdır. Okul öncesi öğretmen ve öğretmen adayları kaynaştırmanın özel gereksinimli çocuğun yetersizlik hissini yaşayabileceği ve dışlanabileceği için zararlı bulduklarını belirtmişlerdir. Ayrıca normal gelişim gösteren çocukların kıskanma ve uyum problemleri gibi sorunlar yaşayabileceğini ve ailelerin olumsuz tepkiler gösterebileceklerini belirtmişlerdir. Bu bulgular Gök ve Erbaş (2011) ile Artan ve Uyanık Balat (2003) tarafından yapılan çalışmalarla paralellik göstermektedir. Adı geçen çalışmalarda okul öncesi öğretmenleri özel gereksinimli çocukların dışlanabileceğini, çocuğun kendini yetersiz hissedebileceğini, ailelerin olumsuz tepkiler gösterebileceğini düşündükleri belirlenmiştir. Koçyiğit (2015) tarafından yapılan çalışmada da özel gereksinimli çocuğun normal gelişim gösteren çocuk ve ailesi tarafından kabul görmeyebilecekleri belirlenmiştir. Yapılan çalışmada hem öğretmenler hem de öğretmen adayları sınıf yönetimi ve zaman yönetimiyle ilgili zorluk yaşanabileceğini belirtmiştir. Benzer şekilde; Saraç ve Çolak (2012), Vural ve Yıkmış (2008), Rakap ve Kaczmarak (2010), Eldeniz Çetin ve Çamlıbel Çakmak (2016), Stoiber, Gettinger ve Goetz (1998) tarafindan yapılan çalışmalarda da öğretmenlerin zaman yönetimiyle ilgili sıkıntılar yaşadıkları belirlenmiştir. Sucuoğlu, Bakkaloğlu, İşcen Karasu, Demir ve Akalın (2014) tarafından yapılan çalışmada öğretmenlerin kaynaştırmaya ilişkin bilgi düzeyleri belirlenmiş ve öğretmenlerin kaynaştırma sınıflarında sınıf yönetimi ve davranış problemleriyle başa çıkma 
konularında bilgi düzeylerinin yeterli düzeyde olmadıkları görülmüştür. Bu sonuç, yukarıda özetlenen çalışmalar ve bu çalışmada öğretmen ve öğretmen adaylarının sınıf yönetimiyle ilgili düşüncelerini açıklar niteliktedir. Bu duruma göre öğretmen ve öğretmen adaylarının kaynaştırma sınıflarında sınıf yönetimine ilişkin bilgi eksikliğinden dolayı kaynaştırmanın dezavantaj olduğunu belirtmiş olabilirler.

Okul öncesi öğretmen adayları; bedensel, işitme, görme engelli çocuklar ve DEHB olan çocukların kaynaştırılabileceğini düşünürken; öğretmenler de benzer cevaplar vermişlerdir. Öğretmen ve öğretmen adaylarının verdikleri bu cevapların daha önce sınıflarında karşılaştıkları özel gereksinim gruplarıyla paralellik gösterdiği görülmektedir. Yapılan çalışmalar, bu araştırmanın bulgularını destekler niteliktedir. Batu, Kırcaali-İftar ve Uzuner (2004) tarafindan yapılan çalışmada kız meslek lisesi öğretmenlerinin zihinsel engelli öğrencilerin kaynaştırılması gerektiğini düşündükleri belirlenmiştir. Bunun sebebinin öğretmenlerin tanıdığı engel gruplarının kaynaştırılmasının daha kolay olduğunu düşünmeleri olarak açıklanmıştır. Çünkü aynı çalışmada öğretmenlerin okullarına yeni gelen işitme engelli öğrencilerin kaynaştırılmasına sıcak bakmadıkları belirlenmiştir. Rakap ve Kaczmarak (2010) tarafından yapılan çalışmada öğretmenlerin özellikle işitme engelli, görme engelli ve otizmli çocukların kaynaştırma eğitimine alınmasına sıcak baktıkları, genel olarak ise tüm engel gruplarının kaynaştırmaya alınabileğini düşündükleri belirlenmiştir. Gök ve Erbaş (2011), Macy ve Carter (1978), Nutbrown ve Clough (2007), Rule, Killoran, Stowitscheck ve Striefel (1985) tarafindan yapılan çalışmalarda da benzer sonuçlar çıktığı görülmektedir. Araştırma sonuçlarına bakıldığında, genel olarak öğretmenlerin daha önce tecrübelerinin olduğu engel grupların kaynaştırılabileceğini düşündükleri söylenebilir.

Okul öncesi öğretmen adayları; zihinsel engelli, ağır ve çoklu yetersizliği olan çocukların kaynaştırılmaması gerektiğini düşünürken; öğretmenler ağır düzeyde engeli olan hiçbir çocuğun alınmaması gerektiğini belirtmişlerdir. Gök ve Erbaş (2011) tarafindan yapılan çalışmada da öğretmenlerin benzer cevaplar verdikleri görülmüsştür. Bu sonuçlar öğretmen ve öğretmen adaylarının Okul Öncesi Eğitim Kurumları Yönetmeliği (2009) ve Özel Eğitim Hizmetleri Yönetmeliği’ne (2016) hâkim olmadığını göstermektedir. Çünkü çocukların kaynaştırma eğitimine alınmaları için ağır ve çok ağır düzeyde zihinsel ve birden çok yetersizliği olmamak şartı aranmaktadır. $\mathrm{Bu}$ durumda öğretmenlerin ve öğretmen adaylarının yönetmeliklere çok hâkim olmadığı sonucu çıkarılabilir.

Okul öncesi öğretmen adayları, kaynaştırmanın başarıya ulaşabilmesi için uygun etkinlikler hazırlanabileceğini, aileyle iletişim içinde kalınabileceğini ve diğer çocuklar ile ailelerinin önyargılarının kırılabileceğini düşünürken, okul öncesi öğretmenleri öncelikle kendilerini geliştirmeleri gerektiğini ve normal gelişim gösteren çocuklar ve ailelerinin hazırlanması gerektiğini düşünmektedirler. Benzer şekilde yapılan çalışmalarda öğretmenlerin aileyle işbirliği yaptığı (Batu, Kircaali-İftar ve Uzuner, 2004; Bradley ve West, 1994; Jonney, Snell, Beers ve Raynes, 1995; Rakap ve Kaczmarek, 2010; Saraç ve Çolak, 2012) sınıfta fiziksel uyarlamalar yaptıkları (Rakap ve Kaczmarek, 2010; Saraç ve Çolak, 2012; Vural ve Yıkmış, 2008) yaptıkları belirlenmiştir. Bu sonuçlardan farklı olarak Temel (2000) tarafından yapılan çalışmada öğretmenlerin kaynaştırmayla ilgili sınıfi uyarlama, etkinlikleri uyarlama, aileyle iletişim gibi konularda bilgi eksiklileri olduğu belirlenmiştir. Bunun sebebinin geçen süre zarfinda kaynaştırmayla ilgili olarak öğretmenlerin daha fazla bilgi ve beceriye sahip olmaları, lisansta kaynaştırmayla ilgili daha fazla eğitim almaları olduğu söylenebilir.

Okul öncesi öğretmen adayları kaynaştırma eğitiminin önemli olduğunu; çünkü her çocuğun eğitim ve firsat eşitliği hakkı olduğunu ve özel gereksinimli çocuğun toplumsallaşması için önemli bir kademe olarak gördüklerini belirtirken; okul öncesi öğretmenleri öncelikle çocuğun gelişim alanlarının desteklenmesi için önemli bulduklarını belirtmişlerdir. Smith ve Smith (2009) tarafindan yapılan çalışmada da öğretmenlerin kaynaştırmayı özel gereksinimli çocuğun sosyal gelişimi ve toplum tarafından kabul edilmesi açısından önemli buldukları belirlenmiştir.

$\mathrm{Bu}$ çalışma sonucunda aşağıdaki öneriler getirilebilir:

- Öğretmen adaylarına özel eğitim dersi kapsamına daha çok uygulama yaptırılabilir.

- Öğretmen adaylarına, kullanacakları yönetmeliklerle ilgili bilgiler verilebilir.

- Karşılaşma sıklığı yüksek olan engel gruplarıyla ilgili lisans dersleri açılabilir ve hizmet içi eğitimler verilebilir.

- Ülke genelinde insanların özel gereksinimli çocuklara karşı önyargılarını kırabilmek için kamu spotları hazırlanabilir, eğitimler ve seminerler verilebilir. 
- Çocuklara farklılıklara saygı kapsamında özel gereksinimli çocuklar ve onlara nasıl davranılması gerektiği anlatılabilir.

\section{Kaynaklar}

Aral, N. (2010). Okul öncesi eğitimde kaynaştırma. İstanbul: MORPA.

Artan, İ. ve Balat, G. U. (2003). Okul öncesi eğitimcilerinin entegrasyona ilişkin bilgi ve düşüncelerinin incelenmesi. Kastamonu Ĕ̈itim Dergisi, 11(1), 65-80.

Batu, S., Kircaali-İftar, G. ve Uzuner, Y. (2004). Özel gereksinimli öğrencilerin kaynaştırıldığı bir kız meslek lisesindeki öğretmenlerin kaynaştırmaya ilişkin görüş ve önerileri [The views and suggestions of teachers of a girls vocational school which includes students of inclusive education]. Ankara Üniversitesi Ĕ̈itim Bilimleri Fakültesi Özel Ĕgitim Dergisi, 5(2), 33-50. Erişim adresi: http://dergiler.ankara.edu.tr/dergiler/39/52/488.pdf

Bradley, D. ve West, F. (1994). Staff training for inclusion of students with disabilities: Visions from school-based educators. Teacher Education and Special Education, 2, 117-128. Erişim adresi: http://journals.sagepub.com/doi/pdf/10.1177/088840649401700206

Buell, M. J., Hallam, R., Gamel-Mccormick, M. ve Scheer, S. (1999). A survey of general and special education teachers' perceptions and inservice needs concerning inclusion. International Journal of Disability, Development and Education, 46(2), 143-156. doi: 10.1080 /103491299100597

Bruns, D. A. ve Mogharreban, C. C. (2007). The gap between beliefs and practices: Early childhood practitioners' perceptions about inclusion. Journal of Research in Childhood Education, 21(3), 229-241. Erişim adresi: https://eric.ed.gov/?id=EJ764545

Creswell, J. W. (2013). Research design: Qualitative, quantitative, and mixed methods approaches. California, CA: Sage publications.

Eldeniz Çetin, M. ve Çamlıbel Çakmak, Ö. (2016). Okul öncesi öğretmenlerinin kaynaştırmaya yönelik ihtiyaçlarının belirlenmesi. The Journal of Academic Social Sciences Studies, 43, 259274. doi: 10.9761/JASSS3260

Glesne C. ve Peskin A. (1992). Becoming a qualitative researcher. White Plains, NY: Longman.

Gök, G. ve Erbaş, D. (2011). Okulöncesi eğitimi öğretmenlerinin kaynaştırma eğitimine ilişkin görüşleri ve önerileri [Early childhood teachers' perceptions about and suggestions for Inclusion Programs]. International Journal of Early Childhood Special Education, 3(1) 66-87. Erişim adresi: http://dergipark.ulakbim.gov.tr/intjecse/article/viewFile/5000016575 15000016395

Güler, A., Halıcıoğlu, M. B. ve Taşğın, S. (2015). Sosyal bilimlerde nitel araştırma yöntemleri. Ankara: Seçkin.

Johnson, R. B. ve Christensen, L. B. (2014). Eğitim araştırmaları nitel, nicel ve karma yaklaşımlar. Ankara: Eğiten Kitap.

Johnson, D. W. ve Johnson, R. T. (1980). Integrating handicapped students into the mainstream. Exceptional children, 47(2), 90-98. Erişim adresi: http://journals.sagepub.com/doi/abs/10.1177 /001440298004700202?journalCode $=$ ecxc

Jonney, R. E., Snell, M. E., Beers, M. K. ve Raynes, M. (1995). Integrating students with moderate and severe disabilities into general education classes. Exceptional Children, 5, 425-439. Erişim adresi: http://journals.sagepub.com/doi/abs/10.1177/001440299506100503?journal Code $=$ ecxc

Koçyiğit, S. (2015). Ana sınıflarında kaynaştırma eğitimi uygulamalarına ilişkin öğretmen-rehber öğretmen ve ebeveyn görüşleri. Uluslararası Türkçe Edebiyat Kültür Ĕ̆itim (TEKE) Dergisi, 4(1), 391-415. Erişim adresi: http://www.tekedergisi.com/Makaleler/735640680_28 koçyiğit.pdf

Leatherman, J. M. (2007). I just see all children as children: Teachers' perceptions about inclusion. The Qualitative Report, 12(4), 594-611. Erişim adresi: https://nsuworks.nova.edu/tqr/vol12 /iss $4 / 5 /$

Lewis, B. R ve Doorlag, D. H. (1987). Teaching special students in the mainstream. London: Merril Publishing Company. 
Özdemir, H. (2010). Okul öncesi öğretmenlerinin kaynaştırma uygulamasına ilişkin görüşlerinin incelenmesi (Yayımlanmamış yüksek lisans tezi). Trakya Üniversitesi Sosyal Bilimler Enstitüsü, Edirne.

Macy, D. J. ve Carter, J. L. (1978). Comparison of a mainstream and self-contained special education program. The Journal of Special Education, 3, 303-313. Erişim adresi: http://journals. sagepub.com /doi/abs/10.1177/002246697801200306

Mastropieri, M. A. ve Scruggs, T. E. (2015). The inclusive classroom: Strategies for effective differentiated instruction. Pearson Higher Ed.

Milli Eğitim Bakanlığı (MEB). (2009). Okul Öncesi Eğitim Kurumları Yönetmeliği. Erişim adresi: http://mevzuat.meb.gov.tr/html /ilkveokuloncyon_0/yonetmelik.pdf.

Milli Eğitim Bakanlığı (MEB). (2016). Özel Eğitim Hizmetleri Yönetmeliği. Erişim adresi: https://orgm.meb.gov.tr/meb_iys_dosyalar/2012_10/10111226_ozel_egitim_hizmetleri_yonet meligi_son.pdf

Nutbrown, C. ve Clough, P. (2007). Inclusion and exclusion in the early years: conversations with European educators. European Journal of Special Needs Education, 19(3), 301-315. doi: $10.1080 / 0885625042000262479$

Rakap, S. ve Kaczmarek, L. (2010). Teachers' attitudes towards inclusion in Turkey. European Journal of Special Needs Education, 25(1), 59-75. doi: 10.1080/08856250903450848

Rule, S., Killoran, J., Stowitschek, J., Innocenti, M. ve Striefel, S. (1985). Training and support for mainstream day care staff. Early Child Development and Care, 20, 99-113.

Salend, S. J. (1998). Using an activities-based approach to teach science to students with disabilities. Intervention in school and clinic, 34(2), 67-72. doi: 10.1177/105345129803400201

Saraç, T. ve Çolak, A. (2012). Kaynaştırma uygulamaları sürecinde ilköğretim sınıf öğretmenlerinin karşılaştıkları sorunlara ilişkin görüş ve önerileri. Mersin Üniversitesi Eğitim Fakültesi Dergisi, 8(1), 13-28. Erişim adresi: http://dergipark.ulakbim.gov.tr/mersinefd/article /view/1002000236

Sarı, H., Celikoz, N. ve Seçer, Z. (2009). An analysis of pre-school teachers' and student teachers' attitudes to inclusion and their self-efficacy. International Journal of Special Education, 24(3), 29-44. Erişim adresi: https://files.eric.ed.gov/fulltext/EJ877918.pdf

Seçer, Z. (2010). An analysis of the effects of in-service teacher training on Turkish preschool teachers' attitudes towards inclusion. International Journal of Early Years Education, 18(1), 43-53. Erişim adresi: https://eric.ed.gov/?id=EJ886092

Smith, M. K. ve Smith, K. E. (2009). "I believe in inclusion, but...”: Regular education early childhood teachers' perceptions of successful inclusion. Journal of Research in Childhood Education, 14(2), 161-180. doi: 10.1080/02568540009594761

Stoiber, K. C., Gettinger, M. ve Goetz, D. (1998). Exploring factors influencing parents' and early childhood practitioners' beliefs about inclusion. Early Childhood Research Quarterly, 13(1), 107-124. Erişim adresi: https://www.sciencedirect.com/science/article/pii /S0885200699800283

Sucuoğlu, B., Bakkaloğlu, H., Karasu, F. İ., Demir, Ş. ve Akalın, S. (2013). Inclusive preschool teachers: Their attitudes and knowledge about inclusion. International Journal of Early Childhood Special Education, 5(2), 107-128. Erişim adresi: http://dergipark.ulakbim.gov.tr /intjecse /article/view/5000016557/5000016363

Sucuoglu, B., Bakkaloglu, H., Iscen Karasu, F., Demir, S. ve Akalin, S. (2014). Preschool teachers' knowledge levels about inclusion. educational sciences. Theory and Practice, 14(4), 14771483. Erişim adresi: https://files.eric.ed.gov/fulltext/EJ1045044.pdf

Şahbaz, Ü. ve Kalay, G. (2010). Okulöncesi eğitimi öğretmen adaylarının kaynaştırmaya ilişkin görüşlerinin belirlenmesi. Mehmet Akif Ersoy Üniversitesi Ĕ̈itim Fakültesi Dergisi, (19), 116135. Erişim adresi: http://dergipark.ulakbim.gov.tr/maeuefd/article/view/1098000188 /1098000086

Temel, F. Z. (2000). Okul öncesi eğitimcilerinin özel gereksinimlilerin kaynaştırılmasına ilişkin görüşleri. H.Ü. Eğitim Fakültesi Dergisi, 18, 148- 155. Erişim adresi: http://www.efdergi. hacettepe.edu.tr/makale_goster.php?id=1090

Vural, M. ve Yıkmış, A. (2008). Kaynaştırma sınıfı öğretmenlerinin öğretimin uyarlanmasına ilişkin yaptıkları çalışmaların belirlenmesi. Abant İzzet Baysal Üniversitesi Eğitim Fakültesi Dergisi, 
8(2), 141-159. Erişim adresi: http://dergipark.ulakbim.gov.tr/aibuefd/article/view/5000091407 15000084779

Yıldırım, A. (1999). Nitel araştırma yöntemlerinin temel özellikleri ve eğitim araştırmalarındaki yeri ve önemi. Eğitim ve Bilim, 23(112), 7-17. Erişim adresi: http://egitimvebilim.ted.org.tr /index.php /EB/ article/ view /5326/1485

Yıldırım, A. ve Şimşek, H. (2011). Sosyal bilimlerde nitel araştırma yöntemleri. Ankara: Seçkin

\section{Extended Abstract}

\section{Introduction}

It is noteworthy that in the first half of the twentieth century, different ideas and efforts for inclusion have begun to be made. The inclusion program initiated in 1913 for visually impaired children is among the first applications. In terms of coalescence, the most striking and fastest developments appeared in the period after 1960s. Inclusion emerged as a philosophy in the 1960s, with the view that equal opportunities for all children should be given, and as a result, special needs children are beginning to be placed in normal classes. In this period, the factors such as the expected benefits of education given in special education classes, the difficulties of adaptation of children in the social direction, the increase of criticism against education given in special education classes, the opening of cases and pressure groups and the making of legal arrangements related to integration became effective.

\section{Method}

This study, which aims to deeply examine and compare the ideas of pre-school teachers and teacher candidates for inclusion, was designed using qualitative research design and case study. The case study is a qualitative approach, in which the researcher collects in-depth information through real-life, up-to-date systems, or multiple sources of information about multiple constrained systems within a given time frame, a description of the situation or a case study (Creswell, 2013). In this study, multiple case studies were used from the case study types. The participants of the study constitute 30 preschool teachers who are working in Samsun and 30 preschool teacher candidates who are studying at On Dokuz Mayis University. Participants were selected according to the maximum diversity sample, which is one of the sampling methods for teacher and teacher candidates. Semi-structured interview technique was used as qualitative research techniques in the research. The semi-structured interview technique is considered suitable for this research because of its flexibility, deepness of the interview, and the ability to obtain in-depth information by adding additional questions to the questions posed. Interview questions were prepared by examining the literature and using informal interviews with preschool teachers and interviewed to three field specialists. The preliminary application of the interview questions was made by a preschool teacher and a teacher different from the teachers participating in the research. The interviews were finalized by way of feedback from this preliminary application. The data obtained in the research were analyzed by content analysis technique. Content analysis is carried out when the research cannot be expressed very clearly theoretically or when a more in-depth analysis is required (Yıldırım \& Şimşek, 2011). The interviews recorded during the interviews were converted into written form by the researchers in the computer environment. Then, all the data obtained in the study were read and coded many times. Various dimensions were determined in accordance with the purpose of the research during the coding, and the themes suitable for these dimensions were determined.

\section{Results and Discussion}

When the answers given in the question of "What is inclusion" of pre-school teachers and teacher candidates were examined, categorization of social development support and others was seen according to the inclusion of answers. Pre-school teachers and prospective teachers categorized their answers to the benefits and harms of inclusion education as benefits for the child with special needs, from the point of view of the normal development child, the teacher, the family of the special needs child and the family of the normally developing child. The answers given by pre-school teachers to the success of the inclusion are categorized as being in terms of special needs child, normal development child, teacher's point of view, family of special needs children and family of normally developing 
children, while teacher candidates were categorized in addition to these categories. It has been seen that children who normally develop have offered something that can be done about their family. Preschool teachers and prospective teachers see the inclusion education as important and categorize the answers as educational and equality of opportunity, importance for the special needs child and as a precaution for the child with normal development. Continuous improvement since its inception has been defined as the training of special needs children in general education classes by teachers (Mastropieri \& Scruguss, 2015). The main purpose of inclusion is to prevent children with special needs from being isolated from their peers and society and to make them see themselves as a part of society. In this study, it is aimed to compare the views of pre-school teachers and prospective teachers towards the inclusion. For this purpose, 30 pre-school teachers and 30 preschool teacher candidates were interviewed semi-structured. As a result of the study, it was seen that the teacher candidates defined the inclusion as mostly education in the general education classes with their special needs child's peers, and the teachers made similar definitions. In parallel with the results of this study, it was determined that teachers in the study conducted by Rakap and Kaczmarek (2010) describe the inclusion of special needs children in general education classes. Similarly, in a study by Stoiber, Gettinger and Goetz (1998), it was determined that teachers describe i inclusion as the acquisition of special needs children in general education classes. Pre-school teachers and teacher candidates indicated that the special needs of the child are harmful because they can experience the feeling of inadequacy and can be excluded. They also stated that normal-progressing children may experience problems such as jealousy and adjustment problems, and that families may show negative reactions. These findings are in parallel with the work done by Gök and Erbaş (2011) and Artan and Uyanık Balat (2003). In the study, both teachers and prospective teachers stated that there may be difficulties in classroom management and time management. Similarly, in the studies conducted by Saraç and Çolak (2012), Vural and Yıkmış (2008), Rakap and Kaczmarak (2010), it was determined that teachers experience problems related to time management. While pre-school prospective teachers are thinking that appropriate activities can be prepared to achieve success, that they can stay in contact with the family and that prejudices of other children and their families may be broken, pre-school teachers think that they need to improve themselves first and that children and families with normal development should be prepared. In the similar studies, physical adaptations of the teachers (Batu, Kircaali-İftar \& Uzuner, 2004; Bradley \& West, 1994; Jonney, Snell, Beers \& Raynes, 1995; Rakap \& Kaczmarek, 2010; Saraç \& Çolak, 2012; Vural \& Yıkmış, 2008) were determined to have done so. 